\title{
地盤の変形を考慮した鉛直荷重時立体架構の実用解法 A PRACTICAL METHOD FOR STRESS ANALYSIS OF SPACE FRAME CONSIDERING DEFORMATION OF THE GROUND UNDER VERTICAL LOADING
}

\author{
松尾雅夫*, 山肩邦男** \\ Masao MATSUO and Kunio YAMAGATA
}

\begin{abstract}
The purpose of this paper is to investigate the reasonable design method of the buildings on poor grounds through the calculation of stresses in superstructure arising from differrential settelement of the foundation. For that purpose, we have proposed the practical method for stress analysis by using the method which is to combine computer program for stress analysis of space frame and deformation of the grounds. By the use of numerical example, we discuss some matter on the relationship between the defferrential settelment of the foundation and the stresses of superstructure. For one thing, it is the influence that the plasticity and creep behavior of the structure's member exert. For another, it is the effect that is got by the method which increases the rigidity of footing beam and column or the method which use floating foundation for the countermeasure of suppression to differrential settlements.
\end{abstract}

Keywords : differential settlement, soil-structure interaction, stress analysis, space frame, non-linear, vertical loading 不同沈下，土之構造物の相互作用，応力解析，立体架構，非線形，鉛直荷重時

\section{1.はじめに}

鉛直荷重をうける架構を設計するにあたっては，従来 から上部構造を下部構造と切り離して, 基礎は沈下しな いものと仮定した構造計算を行ってきた。一方, 下部構 造については上部構造の剛性を無視した沈下計算を行っ ており，その場合の最大沈下量が許容沈下量以内に収ま ることをもって了とする設計レベルにあるのが現状で ある。架構の不同沈下現象を設計面に取り入れるために は, 当然のことながら地盤の変形と上部構造の変形を適 合させて検討されるべきであって，このための実用的な 解析法の出現が久しく望まれてきたところである。

このような観点に立った研究として，1955 年, 横尾・ 山房 ${ }^{21}$ は上部構造の剛性をも考慮した粘土層の圧密過程 を通じての不同沈下理論を発表し，ひきつづいて横尾・ 山肩・佐藤 ${ }^{3}$ は, 軟弱地盤における建築物の不同沈下対 策に関する基礎的考察を行った。また文献 機となって，同様の考え方に基づく不同沈下の計算法が

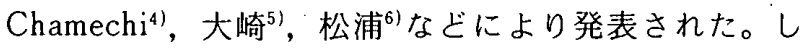
かし，この時代は電算機が実用化される瑤か以前であっ
て, これらの理論の数值解を求めることは非常に面倒で あった。また上部構造の剛性を弾性と仮定しているもの がほとんどであって，わずかに文献りにおいて塑性剛性 およびコンクリート部材のクリープを考慮する必要があ ることを指摘し, 試算を試みている程度であった。そし て,この関連の研究は, 1960 年頃に途絶してしまった。 電算機が発達・普及するに及んで，1980年頃から電 算機の力を借りた研究が現れてきた。すなわち, 中田・ 山肩は, 文献 ${ }^{2)}$ の理論を拡張して杭基礎をもった構造物 の沈下問題を理論化し，実測值との比較検討を行った ${ }^{71}$ 。 次いで, 松浦・山本は上部構造の変形の非線形性および 時間依存性を考慮して圧密過程での沈下挙動を解析 $し^{8)}$ ，またべた基礎を有する構造物の沈下解析を行っ $た^{9)}$ 。土屋 ·大築 - 小幡は粘性土地盤に 3 次元有限要素 解析法を適用して, 構造物の施工過程を通じての直接基 礎および杭基礎建物の沈下挙動を解析した ${ }^{10)}$ 。続いて, 上部構造の解析に $D$ 值法を利用した実用解析法を提案 している゙”。しかしながら、これらの手法を実際の設計 に反映させるには,次のような点に問題があると考える。

\footnotetext{
* 安井建築設計事務所 統括主任・工修

** 関西大学工学部建築学科 教授.工博
}

Yasui Architects \& Engineers, Inc., M. Eng.

Prof., Dept. of Architecture, Faculty of Engineering, Kansai Univ., Dr. Eng. 
1）理論的な精度を追求するあまり, 経時沈下や施工過 程を時間を追って逐次算定する必要があるなよ゙，実設計 に用いるには煩雑にすぎる提案もある。

2）地盤の変形がかなり大きくなる場合があるにもかか わらず，上部構造を弾性として扱っているなど，上部構 造と地盤の構造モデルにかなりの不均衡があること。

3）地盤の変形係数は，応力状態にかかわらず一定とし て扱ったものがほとんどであり，地盤の応力変動が大き い場合や除荷応力が生じる場合には, 対㐫が難しいこと。 4）実用を目的とした算定法では，上部構造の応力算定 に $D$ 值法を利用するなどしており, 現在では一般化し ている剛性マトリクス法による忘力解析法に比べて，解 析精度や架構形状の適用範囲に問題があること。

本論の目的は，基礎の沈下によって生じる建物の挙動 を現状的な精度で推測し，構造物に障害を与えないよう にするための合理的な設計手法を確立することにある。 このため，経時沈下過程は対象とせず，終局的な沈下量 に限定して，実用的な解析法を提案することとした。具

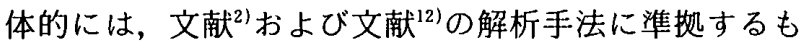
のとし，設計のための現実的な観点に立って，新たに次 の諸項目を導入した。

1）上部構造を立体架構として扱い，設計に多用されて いる 3 次元骨組解析プログラムと地盤変位を連繋させる という手法によって，不同沈下による建物の設計用応力 を直接求められるようにした。

2）粘性土の変形係数は, 有効応力の大きな変動, 掘削 などの娍少応力による地盤の変形，さらに近接盛土や隣 接建物などが対象建物に与える沈下の影響などをも取り 扱えるよう， $e \sim \log P$ 関係に基づいた体積王縮係数 $m_{v}$ の逐次設定法を採用した。したがって，粘性土の過 圧密・正規圧密・圧密未了状態を通じての解析が可能と なる。

3）砂質土を対象とした即時沈下の計算では，地盤剛性 のひずみ依存性を考虑し，地盤の弾性係数を地盤のひず みにより変化させる関係式を取り入れた。

4）現実の構造物の挙動をより精度よく推測するため, 上部構造部材の塑性化およびクリープ性状を考慮できる ようにした。

この解析法の適用性を検討し，かつ不同沈下現象と諸 因子との関係を調査するため，モデル建物に種々の条件 を与えた場合の応力解析を行った。結果として，上部構 造の剛性が不同㶩下量や部材応力に及ぼす影響，上部構 造部材に塑性化やクリープ変形を考慮した場合の影響, 粘性土の各種有効応力状態（過圧密・正規圧密・圧密未 了）による影響，不同沈下軽減方法などについて，定量 的な検討を行うことができた。

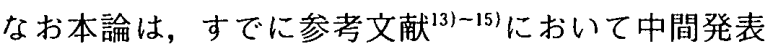
を行っていることをお断りしておく。

\section{2. 地盤の変形を考慮した上部架構応力の算定法}

本解析法の対象・誘導上の仮定および考慮事項等は, 以下のごとくである。

1）原則として，直接基礎を対象とする。ただし，杭基 礎については，仮想の基礎荷重面を杭先端部あるいは杭 中間部に設定する方法などにより，近似的に扱うことが 可能と考える。

2）地盤の変形は即時沈下および終局圧密沈下に限るも のとし，圧密沈下過程は対象外とする。

3）即時沈下は，砂質土・粘性土層ともに地盤の互層状 態に対して, Steinbrenner の多層近似解法 ${ }^{16)}{ }^{17)}$ を用い て算定する。なお，地盤の弾性係数はひずみ依存性を考 慮する。

4）粘性土の圧密沈下は 1 次元圧密として扱い, 地中応 力の伝達については地盤の互層状態にかかわらず,

Boussinesq の理論解を基本とした解を用いる。変形係 数としては，体積圧縮係数 $m_{v}$ を採用するが， $m_{v}$ は圧 密試験加得られる $e \sim \log P$ 関係曲線上の有効応力に 応じた値を設定する。

5）上部構造は立体架構とするが，部材のねじれ剛性， 梁の弱軸方向の剛性は無視する。また，部材の塑性化に 伴う剛性低下や，クリープを考慮する。

\section{1 地盤変位の関係式}

地盤変位の関係式は，文献をを終局沈下量に限って適 用した文献 ${ }^{12)}$ の手法に従う。

\section{（1）粘性土層の圧密沈下}

図一1に示すように, 地盤は互層状態にあるものとし,
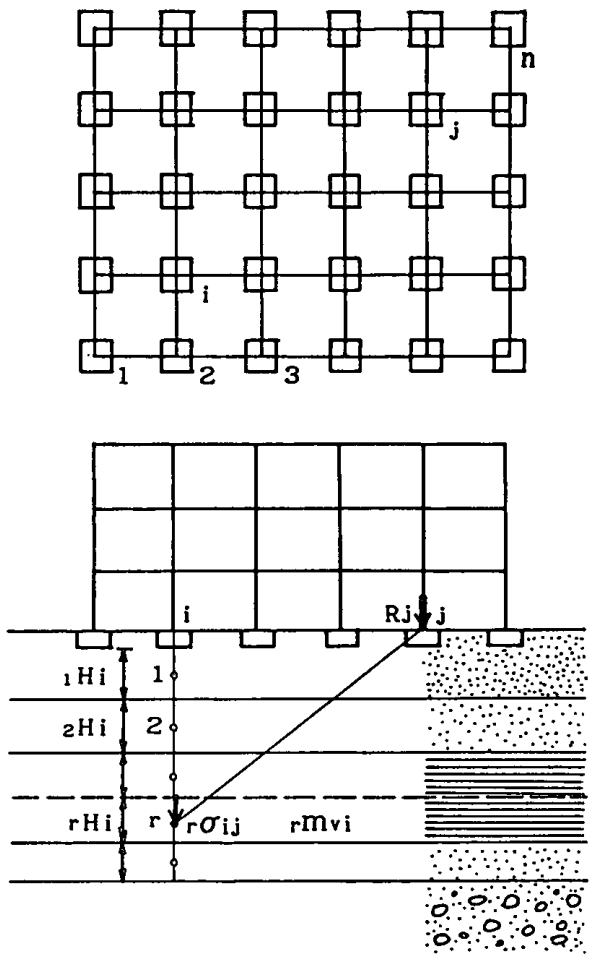

図一1＼cjkstart地盤上の立体架構 
任意の $i$ 基礎の圧密沈下量を（1）式で表す。

$$
\begin{gathered}
S_{i c}=\sum_{r}{ }_{r} m_{v i}{ }^{\circ} H_{r} H_{i}{ }_{r} \sigma_{i}=\sum_{r}{ }_{r} \lambda_{i}=\sum_{j}{ }_{r} \sigma_{r} \alpha_{i j} \cdot{ } \cdot R_{j} \\
\end{gathered}
$$

ここに, $S_{i c}$ は $i$ 基礎の圧密沈下量, ${ }_{r} \lambda_{i}={ }_{r} m_{v i}{ }_{r} H_{i}$ は 粘性土層定数 ( $i$ 基礎直下の第 $r$ 層の体積王縮係数 $\times$ 層厚), $r \sigma_{i}$ は $i$ 基礎直下の第 $r$ 層中央位置の有効応力 増分, ${ }_{r} \alpha_{i j}$ は応力伝達係数 ( $j$ 基礎の単位荷重によって $i$ 基礎直下の第 $r$ 層に生ずる応力)， $R$, は $j$ 基礎の鉛直 荷重である。

各粘性土層に作用する有効応力増分を層中央高さの值 で代表させているので，層厚が厚い場合には適宜分割し て数層から成るものとする。 ${ }_{r} m_{v i}$ および ${ }_{r} H_{i}$ を用いる ことにより, 地層の局部的な変化をも考虑することがで きる。応力伝達係数は, 例えば長方形等分布面荷重の隅 角部直下の場合には, Steinbrenner の半無限弾性体の 理論解から（2）式で与えられる。（2）式に長方形分 割法を適用すれば， ${ }^{2} \alpha_{i j}$ が計算できる。

$$
\begin{aligned}
\alpha= & \frac{1}{2 \pi \cdot m z \cdot n z}\left\{\frac{m \cdot n}{\sqrt{m^{2}+n^{2}+1}} \cdot \frac{m^{2}+n^{2}+2}{\left(m^{2}+1\right)\left(n^{2}+1\right)}\right. \\
& \left.+\sin ^{-1} \frac{m \cdot n}{\sqrt{\left(m^{2}+1\right)\left(n^{2}+1\right)}}\right\} \cdots \cdots \cdots \cdots \cdots(2)
\end{aligned}
$$

ここに, $m z, n z$ は長方形面荷重の各々の辺長, $z$ は 長方形面荷重隅角部からの深さである。なお， $z$ が十分 大であれば, Boussinesq の集中荷重による応力理論解 から直接 ${ }_{r} \alpha_{i j}$ を計算することができる。

\section{(2) 即時沈下}

任意の $i$ 基礎の即時沈下量を（3）式で表す。

$$
S_{i e}=\sum_{r}\left(\sum_{j} \gamma_{i j} \cdot R_{j}\right)
$$

ここに, $S_{i e}$ は $i$ 基礎の即時沈下量, ${ }_{r} \gamma_{i j}$ は即時沈下 係数 $(j$ 基礎の単位荷重による $i$ 基礎直下第 $r$ 層の即 時沈下量)である。

即時沈下係数は, 例えば有限厚さの地層の場合, 長方 形等分布面荷重の隅角部ではSteinbrenner の解 ${ }^{61}$ によ り (4) 式で与えられる。

$$
\begin{aligned}
\gamma= & \frac{1}{E \cdot L}\left(1-\nu^{2}\right) F_{1}+\left(1-\nu-2 \nu^{2}\right) F_{2} \cdots \cdots \\
F_{1}= & \frac{1}{\pi}\left\{n_{L} \cdot \log \frac{\left(1+\sqrt{n_{L}^{2}+1} \cdot \sqrt{n_{L}^{2}+n_{D}^{2}}\right)}{n_{L}\left(1+\sqrt{n_{L}^{2}+n_{D}^{2}+1}\right)}\right. \\
& \left.+\log \frac{\left(n_{L}+\sqrt{n_{L}^{2}+1}\right) \sqrt{1+n_{D}^{2}}}{n_{L}+\sqrt{n_{L}^{2}+n_{D}^{2}+1}}\right\} \\
F_{2}= & \frac{n_{D}}{2 \pi} \tan ^{-1} \frac{n_{L}}{n_{D} \cdot \sqrt{n_{L}^{2}+n_{D}^{2}+1}}
\end{aligned}
$$

ここに, $L$ は長方形の長辺長さ， $B$ は長方形の短辺 長さ， $E$ は地盤の弹性係数, $\nu$ は地盤のポアンン比, $n_{L}$ は $L / B, n_{D}$ は $Z / B, Z$ は長方形面荷重隅角部直下 の層厚である。この解に, 長方形分割法および多層地盤 への重站合わせ法 ${ }^{(7), 18)}$ を適用することによって, ${ }_{r} \gamma_{i j}$ が 求められる。

\section{（3）終局沈下の関係式}

圧密沈下および即時沈下の両方が生じる場合には， $i$ 基礎の沈下量は（1）および（3）式を加えた（5）式 となる。

$$
S_{i}=S_{i c}+S_{i e}=\sum_{r}{ }_{r} \lambda_{i} \cdot\left(\sum_{j} \alpha_{i j} \cdot R_{j}\right)+\sum_{r}\left(\sum_{j}{ }_{r} \gamma_{i j} \cdot R_{j}\right)
$$

すべての基礎について（5）式が成り立ち，全基礎の视 下量と鉛直荷重の関係は（6）式のマトリクスで表され る。

$$
\left\{S_{R}\right\}=[F] \cdot\left\{R_{R}\right\} \cdot
$$

ここに，\{S $\}$ は基礎の沈下量, $[F]$ は地盤変位の柔性 マトリクス, $\left\{R_{F}\right\}$ は基礎の鉛直荷重である。

\section{2 上部架構の関係式}

上部架構については, 各節点において 6 自由度の変位 $\left(x, y, z, \theta_{x}, \theta_{y}, \theta_{z}\right)$ をもつ立体架構の解析プログラ ムが汎用されており, 全架構の関係式は (7) 式のマト リクスで表される。このうち, 部材のねじれ剛性および 梁の弱軸剛性は, 一般の建物では架構応力にほとんど影 響を与えないため無視することとした。

$$
\{R\}=[K] \cdot\{D \mid \cdot
$$

ここに, $\left\{R \mid\right.$ は節点外力 $\left(X, Y, Z, M_{x}, M_{y}, M_{z}\right)$, $[K]$ は架構全体の剛性マトリクス, $\{D\}$ は節点変位であ る。

\section{3 地盤変位を考愿した上部架構の関係式}

（6）式を $\left\{R_{F}\right\}=[F]^{-1} \cdot\left\{S_{F}\right\}$ に置換し, 地盤の剛性マト リクス $[F]^{-1}$ を $(7)$ 式の架構全体の剛性マトリクス $[K]$ の基礎位置節点鉛直成分に付加することにより，地 盤変位を考慮した上部架構全体の関係式を得ることがで きる。

\section{3. 地盤の非線形性の扱い}

\section{1 粘性土の圧密沈下}

建物建設後の圧密沈下は，建物建設前の粘性土の圧密 状態（過圧密・正規圧密・压密未了など），建設前後の 有効圧の相対的な大きさなどによって影響される。この ような粘性土の圧密状態および有効応力の広範囲な変動 領域に対忘するため，本解法では $e \sim \log P$ 関係に則っ て体積圧縮係数 $m_{v}$ を変動させる手法を採用した。

\section{（1）過圧密および正規圧密地盤での手法}

圧密試験結果から得られた $e \sim \log P$ 曲線は, 設計用 の $e \sim \log P$ 関係として図一2 のようにモデル化するこ とができる。図中の $\mathrm{AC}$ 線の勾配は膨張指数 $C_{s}$ を, $\mathrm{CB}$ 線の勾配は圧縮指数 $C_{c}$ を, $\mathrm{C}$ 点の有効応力は圧密 降伏応力 $P_{c}$ を表す。任意の有効応力に対応する体積圧 縮係数 $m_{v}$ は，（8）および（9）式によって $C_{s}$ また は $C_{c}$ を用いて求めることができる。

$$
m_{v}=\frac{\left.C_{c} \text { (または } C_{s}\right)}{\left(1+e_{1}\right) \cdot \Delta P} \cdot \log \left(\frac{P_{1}+\Delta P}{P_{1}}\right)
$$




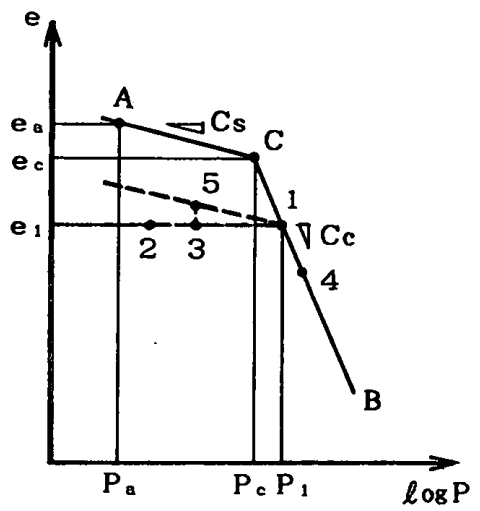

図一2 $e-\log P$ 曲線のモデル化

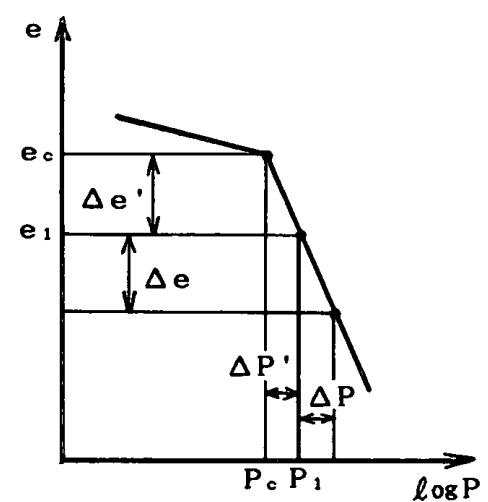

图一3 圧密未了地盤の $e \sim \log P$ 関係

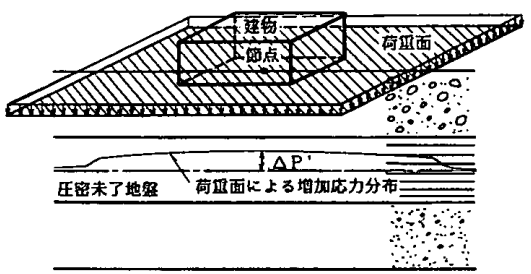

図一4 圧密末了地盤の適用手法

$$
\begin{aligned}
& e_{1}=e_{a}-C_{s} \times \log \left(\frac{P_{1}}{P_{a}}\right) \\
& e_{1}=e_{c}-C_{c} \times \log \left(\frac{P_{1}}{P_{c}}\right)
\end{aligned}
$$

ここに, $P_{1}, e_{1}$ は任意点の有効応力および間隙比, $P_{a}, P_{c}, e_{a}, e_{c}$ は図一2に示す各点の有効応力および間 隙比, $\Delta P$ は $P_{1}$ からの有効応力増分である。

解析にあたっては, 上部構造の荷重を区分し, その区 分荷重を順次載荷していく荷重増分法を採用する。図一 $2 の e \sim \log P$ 関係を評価するため, 各載荷ステップご とに累積された地盤中の各点の有効応力が過王密領域か 正規圧密領域かを判定し（8）および（9）式によっ て次ステップの $m_{v}$ を逐次設定しなおす。

この方法により過圧密から正規圧密状態にいたる粘性 土の沈下性状を考慮することが可能となる。

\section{（2）纴密末了地盤での手法}

圧密末了地盤では，図一-3の $e \sim \log P$ 関係において 現状の有効応力 $P_{1}$ が任密降伏応力 $P_{c}$ より大きく, 建 物荷重による有効応力増分 $\Delta P$ によって生じる沈下以 外に, $P_{c} \sim P_{1}$ 間 $\left(e_{c} \sim e_{1}\right.$ 間) で建物荷重とは無関係に 沈下が生ずる。本解法ではこのような現象を扱うために, 図一4のように $P_{c} \sim P_{1}$ 間の圧密末了の原因となってい る荷重面を建物とは別に設定する。この荷重面によって, $P_{c} \sim P_{1}$ 間の圧密末了部分の沈下量を評価する。その際, 設定した圧密未了部分に相当する荷重をまず載荷し，そ の後に建物荷重を載荷するものとする。この手法を利用 すれば建物荷重とは無関係に作用する荷重をも扱うこと ができる。例えば, 周辺の建物や盛土の荷重, 排土重量 などの影響も考慮することが可能となる。

\section{2 即時视下}

即時沈下の計算式に用いる地盤の弾性係数は, 地層の ひずみ（応力）が大きくなるほよ゙その值が低下するひず み依存性を有している。このような現象を考慮するため, 地盤や建物の浮き上がり, 沈下測定のシミュレーション 結果に基づいて評価弾性係数を提案している秋野(9)にな らい，(10）式により地盤の弾性係数を評価することと

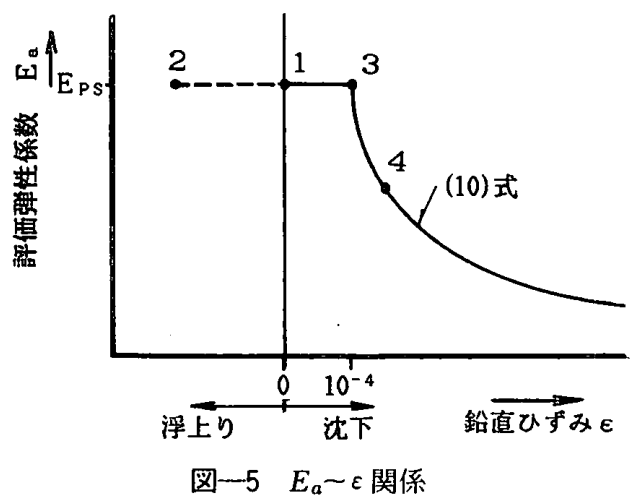

する（図一 5 参照）。

$$
E_{a}=\left(\varepsilon / 10^{-4}\right)^{-0.55} \cdot E_{P S}
$$

ここに, $E_{a}$ は評価弾性係数 $\left(E_{a} \leqq E_{P S}\right), E_{P S}$ はPS 検層より求めた弾性係数， $\varepsilon$ は地層の鉛直方向のひずみ である。解析は，王密沈下と同様に各増分ステップにお いて，その時点での各層の鉛直ひずみから（10）式によ り次ステップの地盤の弾性係数を逐次求めていく方法に よる。

3.3 浮基礎における地盤定数の扱い

除荷・再載荷過程を伴う浮基礎建物の地盤定数に関し ては，以下のように設定する。

（1）粘性土

掘削により粘性土層の応力は诚少するが，建物建設ま での短い期間では，粘性土層に間隙水が供給されないた め浮き上がりは生じない。すなわち, 図一2の $e \sim \log$ $P$ 関係において, 排土前の有効応力点 1 から水平に点 2 まで移動すると考える。その後, 建物荷重による応力 の増加に伴って, 点 2 から点 1 , さらに点 4 に向かって 再び移動する。しかし，増加応力が娍少応力より小さく て, 建物荷重載荷後の応力が点 3 によよ゙まる場合には, 終局時において間隙水は飽和されているので, 点 3 と同 じ応力で排土前の有効応力点 1 から膨張係数線に平行な 線上の点 5 に移動し，粘性土の浮き上がりが生ずるもの と考える。

(2) 砂質土 
砂質土の浮き上がりおよび沈下の計算は即時沈下の計 算式を用いる。この計算に用いる弾性係数は，除荷およ び再載荷時でひずみが $1 \times 10^{-4}$ までは初期弾性係数 $E_{P S}$ とし，再載荷時でひずみが $1 \times 10^{-4}$ を超える場合には

(10) 式を用いて算定する。すなわち，図一5の $E_{a} \sim \varepsilon$ 関係において, 除荷時には点 1 から点 2 , 再載荷時に は点 2 から点 3 さらに点 4 へと移動するものと考える。

\section{4. 上部架構の非線形性の扱い}

建物の不同沈下解析を行うと, しばしば上部架構に過 大な不同㶩下忘力が発生し，コンクリート系部材の弾性 限応力を超えていることも多い。また，現実に観測され ている不同㶩下量と弾性的な解析結果の間にはかなりの 相違が認められる。これらは, 部材の塑性化やクリープ 変形による剛性低下現象を考えないと説明できない。し たがって, 本解法ではコンクリート系部材に限って,こ れらの現象を以下の方法により考慮する。

\section{1 部材の塑性化による曲げ剛性低下}

鉄筋コンクリート部材の $M-\theta$ 関係を, 図一6に示す トリリニア型の直線に近似する。図中の記号は, $M_{c r}$ ： 曲げひび割れモーメント， $M_{y}$ ：曲げ降伏モーメント, $K_{e}$ : 初期曲げ剛性, $\alpha_{0}$ : 第 2 勾配の剛性低下率, $\alpha_{y}$ : 降伏時剛性低下率を示す。 $M_{c r} \cdot M_{y} \cdot \alpha_{y}$ は文献 ${ }^{20)}$ ながら 求めることができ， $\alpha_{0}$ は幾何学的な関係により (11) 式で求めることができる。

$$
\begin{aligned}
& \alpha_{0}=\frac{M_{y}-M_{c r}}{M_{y} / \alpha_{y}-M_{c r}} \\
& M \leqq M_{c r} \text { の場合 } \quad K_{e y t}=K_{e} \\
& M_{c r}<M \leqq M_{y} \text { の場合 } K_{e y i}=\alpha_{0} \cdot K_{e} \\
& M_{y}<M \quad \text { の場合 } K_{e y i}=0.01 \cdot K_{e}
\end{aligned}
$$

ここに， $K_{\text {eyi }}$ は $i$ ステップでの塑性化による等価曲 げ剛性である。各増分ステップごと，各部材ごとに曲げ 応力の值を判定し, 次ステップの曲げ剛性を設定する。 なお， $M_{y}$ を超えた場合には塑性ヒンジを想定するかわ りに，便宜的に曲げ剛性を $K_{e}$ の $1 / 100$ に低下させて対 応する。

\section{2 コンクリートのクリープ変形}

コンクリートの゚クリープひずみは一般に，長期許容応 力度程度以下の低応力域では応力に対して線形であると

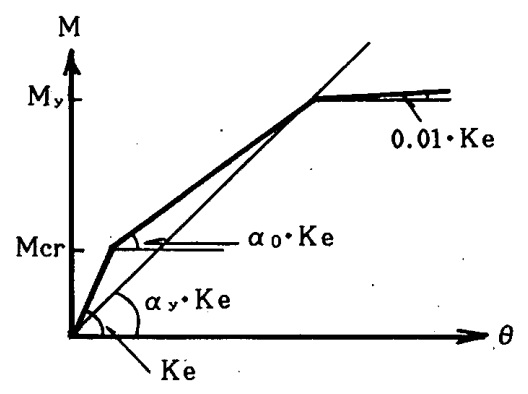

図一6 $M \sim \theta$ 関係の近似
みなされている。それ以上の応力になると，非線形性を 示すことが知られているが，定量的に参考となるような 文献はほとんよ゙見当らないようである゙1)。まして，不同 沈下応力を対象とし，鉄筋コンクリート部材に曲げひび 割れが発生し曲げ降伏に至るような高応力に対するク リープの挙動については，いまだに調査研究が及んでい ない領域といえよう。しかし，現実に生じている鉄筋コ ンクリート建物の不同沈下現象の程度は, このような高 応力下でのクリープを考慮に入れなければ推論すること は不可能である。

したがって, 本解析法では思い切った近似化を行って, 以下のような仮定のもとに検討することとした。すなわ ち, コンクリートのクリープひずみはすべての応力域に おいて応力との間に線形関係が成り立つものとし，かつ 曲げを受ける鉄筋コンク!ート断面に対して，(12）式 および (13) 式が適用できるものとする。

$$
\left.\begin{array}{l}
\Delta \theta_{t}=\frac{M}{K_{e}} \phi_{m t}, \quad K_{e c t}=\frac{1}{1+\phi_{m t}} \cdot K_{e} \cdots \\
\phi_{m t}=(1-\beta) \phi_{t}, \quad \beta=\frac{n \cdot q}{1-n \cdot q} \\
\phi_{t}=\frac{0.75 t}{1.5+0.25 t} \quad(t \text { は週単位 })
\end{array}\right\}
$$

ここに， $\Delta \theta_{t}$ は曲げモーメント $M$ によって生ずる時 間 $t$ におけるクリープ回転角ひずみ， $K_{e c t}$ は曲げモ一 メント $M$ によって生ずる時間 $t$ におけるクリープ回転 角ひずみを考慮した等価曲げ剛性， $\phi_{m t}$ は曲げに対する 鉄筋コンクリート断面の等価クリープ係数, $n$ は鉄筋と コンクリートのヤング係数比 $\left(E_{s} / E_{c}\right), q$ は鉄筋とコ ンクリートの断面 2 次モーメント比 $\left(I_{s} / I_{c}\right), \phi_{t}$ はコン クリートのクリープ係数である。

本解析法では終局沈下を対象亡しているため, コンク リートのクリープ係数は $\phi_{t}=3(t=\infty)$ を採用する。 なお,塑性化とクリープ変形を同時に考慮する場合には, 図一6の $M \sim \theta$ 関係の曲げ剛性に $1 /\left(1+\phi_{m t}\right)$ を乗じて (15) 式により任意ステップでの等価曲げ剛性 $K_{e y c i}$ を 求める。

$$
K_{\text {eyci }}=K_{\text {eyi }} \times \frac{1}{1+\phi_{m t}}
$$

\section{5. 直接基礎建物の不同沈下解析例}

5.1 解析モデルと設定条件

図一7に示す長辺 5 スパン，短辺 3 スパン， 3 層の鉄 筋コンクリート造ラーメン（文献 ${ }^{201}$ の構造計算例 1 を参 考とした）について解析を行う。地盤条件は，図一8に 示す地層が水平方向に一様な場合を想定し，砂質土層は 即時沈下のみ, 粘性土層は王密沈下のみが生じるものと した。粘性土層の圧密状態は, 過圧密・正規圧密 - 圧密 末了の場合をそれぞれ想定し，便宜的に $e \sim \log P$ 関係 は同一として,初期有効生のみが異なるものと設定した。 
解析用の地盤定数, 粘性土の $e$ $\log P$ 関係, 初期有効王, (10) 式 における $E_{P S}$ の值などは図一8中に 示した。なお，玨密未了の場合の荷 重面の分布域は, 建物の各辺長さの 5 倍と想定する。

基礎形式は独立基礎とし，フーチ ングの大きさはすべて $3.0 \mathrm{~m} \times 3.0$ $\mathrm{m}$ 角とした。部材断面は設定載荷 重に対し，不同沈下が生じない場合 には，十分許容応力度に収まるよう に決定してあり，柱は各階ごと，梁 は各階ごとおよび方向別に同じ断面 を設定した。表一1にこれらの諸元 を示した。なお，柱の $M_{y}$ 計算用の 軸力は建物内部柱 (X 3-Y 2) に代 表させて，各階ごとに同じと仮定し た。建物荷重は全体として $5 \mathrm{tf} / \mathrm{m}^{2}$ ( $\mathrm{R}$ 階 $0.8,3$ 階 2 階 1.2, 1 階 $\left.1.8 \mathrm{tf} / \mathrm{m}^{2}\right)$ とし, 各階柱位置にその 負担面積を乗じたものを集中荷重と して作用させた。図一6の $M \sim \theta$ 関 係については, 不同沈下による曲げ モーメント $M$ のみを考虑し, 通常 のラーメン計算（基礎不動）による 曲げモーメントとの複合は考えない ものとする。

解析は, 即時沈下, 過圧密・正規 圧密・圧密末了状態での圧密沈下, 上部架構の部材の塑性化・クリープ 変形の影響などの検討を条件とし て，表一2に示すCASE-0〜7を設 定した。また不同沈下の軽減対策と して, 柱の剛性を一定として基礎梁 の剛性を増加させた場合および浮基 礎を採用した場合についての検討, すなわち, 表一2 中の CASE-8 A $8 \mathrm{G}$ および CASE-9 を設定した。 ただし, 前者では基礎梁成の増加に よる掘削深さの増加は無視した。ま た後者では, 浮基礎の排土重量が建 物荷重とほぼ等しい $5.4 \mathrm{tf} / \mathrm{m}^{2}$ の場 合を考え，GL-4.0 $\mathrm{m}$ まで掘削を 行った後に浮き上がりによるレベル 差を整地し，建物が建設されるものとした。なお，1階 柱の剛性を変化させた場合についても検討を行ったが， 表一2 中からは除いてある。

\section{2 解析結果}
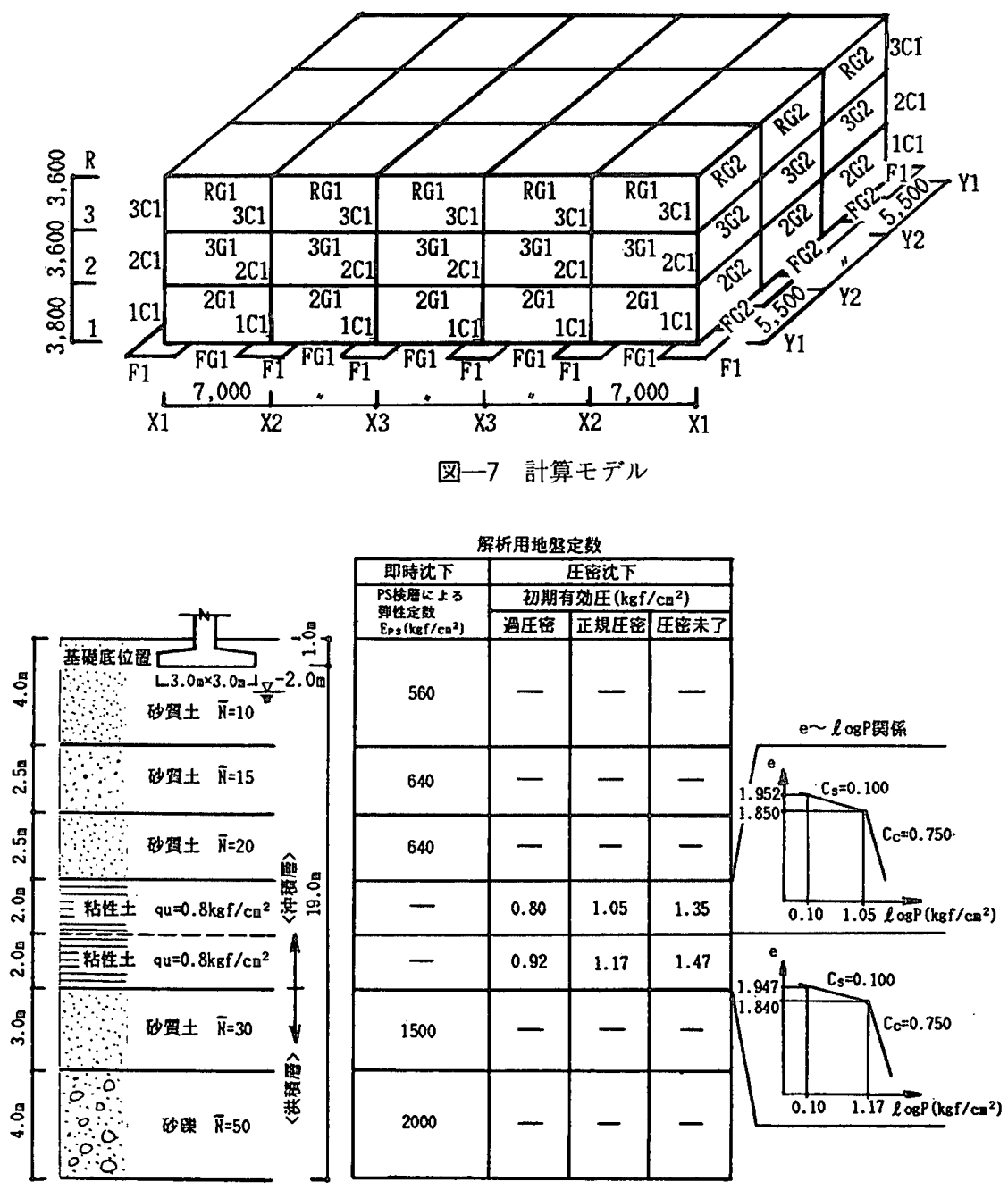

図一8 地盤条件

表一1 部材の諸元

\begin{tabular}{|c|c|c|c|c|c|c|c|c|c|c|}
\hline \multirow{2}{*}{ 符号 } & \multirow{2}{*}{$D \times b(c m)$} & \multirow{2}{*}{ 主觔本数 } & \multirow{2}{*}{$\begin{array}{c}\mathrm{K}_{\circ} \\
\left(\times 10^{5} \mathrm{tfca}\right) \\
\end{array}$} & \multicolumn{5}{|c|}{ 塑姓化に関する数值 } & \multicolumn{2}{|c|}{ 们ー゙に関する数値 } \\
\hline & & & & 漸力 $(\mathrm{t} f) \mid$ & $M_{c r}(t f n)$ & $M_{y}\left(t f_{a}\right)$ & $\alpha_{y}$ & $a_{a}$ & $\beta$ & $\phi_{m t}$ \\
\hline $3 \mathrm{Cl}$ & $60 \times 60$ & $\begin{array}{l}(X) 3-D 22 \\
(Y) 3-D 22\end{array}$ & 3.78 & 30.8 & 12.4 & 28.1 & 0.20 & 0.12 & 0.066 & 2.802 \\
\hline $2 \mathrm{Cl}$ & $60 \times 60$ & $\begin{array}{l}(\mathrm{X}) 4-\mathrm{D} 22 \\
(\mathrm{Y}) 4-\mathrm{D} 22\end{array}$ & 3.78 & 77.0 & 17.0 & 36.3 & 0.24 & 0.14 & 0.091 & 2.727 \\
\hline $1 \mathrm{Cl}$ & $60 \times 60$ & $\begin{array}{l}(\mathrm{X}) 5-\mathrm{D} 22 \\
(\mathrm{Y}) 5-\mathrm{D} 22\end{array}$ & 3.58 & 123.2 & 21.4 & 62.8 & 0.28 & 0.20 & 0.093 & 2.721 \\
\hline RG1 & $70 \times 35$ & $\begin{array}{l}\text { (上) 3-D22 } \\
\text { (下) 3-D22 }\end{array}$ & 18.0 & 0.0 & 7.5 & 23.8 & 0.31 & 0.24 & 0.100 & 2.700 \\
\hline $3 G 1$ & $70 \times 35$ & $\begin{array}{l}\text { (上) 4-D22 } \\
\text { (下) 4-D22 }\end{array}$ & 18.0 & 0.0 & 7.5 & 31.7 & 0.34 & 0.28 & 0.138 & 2.586 \\
\hline 201 & $75 \times 40$ & $\begin{array}{l}\text { (上) 4-D22 } \\
\text { (下) 4-D22 }\end{array}$ & 25.3 & 0.0 & 9.8 & 34.1 & 0.31 & 0.24 & 0.114 & 2.685 \\
\hline $\mathrm{RC2}$ & $70 \times 30$ & $\begin{array}{l}\text { (上) 3-D22 } \\
\text { (下) 3-D22 }\end{array}$ & 19.6 & 0.0 & 6.4 & 23.1 & 0.28 & 0.22 & 0.119 & 2.643 \\
\hline $3 \mathrm{G} 2$ & $70 \times 30$ & $\begin{array}{l}\text { (上) 4-D22 } \\
\text { (下) 4-D22 }\end{array}$ & 19.6 & 0.0 & 6.4 & 31.7 & 0.32 & 0.27 & 0.116 & 2.652 \\
\hline $2 \mathrm{CO}$ & $75 \times 35$ & $\begin{array}{l}\text { (上) 4-D22 } \\
\text { (下) 4-D22 }\end{array}$ & 28.2 & 0.0 & 8.6 & 34.1 & 0.29 & 0.23 & 0.133 & 2.601 \\
\hline FG1 & $120 \times 40$ & $\begin{array}{l}\text { (上) 5-D22 } \\
\text { (下) 5-D22 }\end{array}$ & 104.0 & 0.0 & 25.0 & 70.1 & 0.22 & 0.15 & 0.092 & 2.724 \\
\hline $\mathrm{FG} 2$ & $120 \times 40$ & $\begin{array}{l}\text { (上) 5-D22 } \\
\text { (下) 5-D22 }\end{array}$ & 132.0 & 0.0 & 25.0 & 70.1 & 0.19 & 0.13 & 0.092 & 2.724 \\
\hline F1 & $\begin{array}{l}\ell x=300 \\
\ell y=300\end{array}$ & & & & & & & & & \\
\hline
\end{tabular}

計算結果の沈下量および反力の分布を図一 9 に, Y 2 通り・X 3 通りラーメンの曲げモーメント分布を図-10 に，代表的な計算 CASE に関して示した。またここれ らのラーメンの最外端スパンの変形角と梁の曲げモーメ 
ントの関係を表一 3 に，かつその一部を 図一11に示した。これらの図表より， 以下のことが指摘できる。

1) CASE-0 と CASE-1 を比較する と，上部構造の剛性を考虑することによ り沈下量が均等化（最大変形角 $6.80 \times$ $\left.10^{-3} \rightarrow 2.51 \times 10^{-3} \mathrm{rad}\right)$ されるとともに， 荷重が建物中央部から外端部に移行して いる様子がわかる。ただし，上部構造に は不同沈下応力がかなり発生しており， 最外端のスパンでは基礎梁から R 階梁ま でのほとんどが降伏毛ーメントを超えて いて，部材を弾性とした CASE-1 の計 算結果は現実的でないといえる。
表一2 解析 CASE と考虑因子

\begin{tabular}{|c|c|c|c|c|c|c|c|c|c|c|}
\hline & E部架 & & & 压密沈T & & 工部架 & 檽部材 & 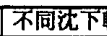 & 涯淈对策 & \\
\hline CASE名 & 無視 & 即時沈下 & 過圧密 & 正規圧筽 & 仼密未了 & 塑性化 & タリーフ & 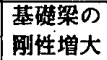 & 浮基碀 & 嘴 考 \\
\hline$\overline{\mathrm{ASSE}-0}$ & 0 & & & 0 & & & & & & \\
\hline CASE-1 & & & & 0 & & & & & & 摽雮モデル \\
\hline$\overline{\mathrm{CASE}-2}$ & & & & 0 & & $\mathrm{O}$ & & & & \\
\hline CASE-3 & & & & 0 & & 0 & 0 & & & \\
\hline ASE-4 & & & O & & & 0 & & & & \\
\hline$\overline{\mathrm{AASE}-5}$ & & & & & 0 & $\mathrm{O}$ & & & & \\
\hline CASE-6 & & 0 & & & & 0 & & & & \\
\hline ASE-7 & & 0 & & 0 & & 0 & & & & \\
\hline ASE-8A & & & & 0 & & 0 & & 2 倍 & & TASE-2の基 \\
\hline $8 B$ & & & & 0 & & 0 & & 5 倍 & & 绩梁の曲け \\
\hline 80 & & & & 0 & & $\mathrm{O}$ & & 10倍 & & 佣性耐力を \\
\hline 80 & & & & 0 & & 0 & & 20 谙 & & 增大させた \\
\hline 86 & & & & 0 & & O & & 50倍 & & モデル \\
\hline 8 & & & & 0 & & $\mathrm{O}$ & & 100 倍 & & \\
\hline 86 & & & & $\mathrm{O}$ & & O & & (50倍) & & 协周部のみ \\
\hline ASE-9 & & 0 & & $\mathrm{O}$ & & 0 & & & 0 & \\
\hline
\end{tabular}

CASE-0

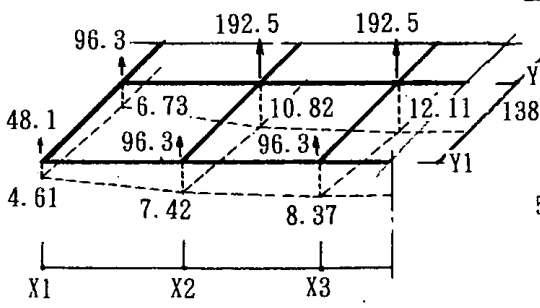

CASE-3

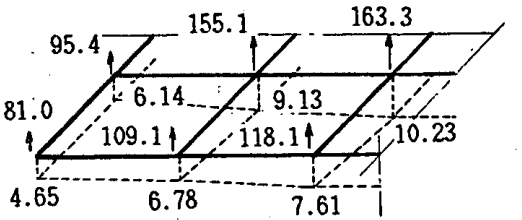

CASE-6
CASE-1

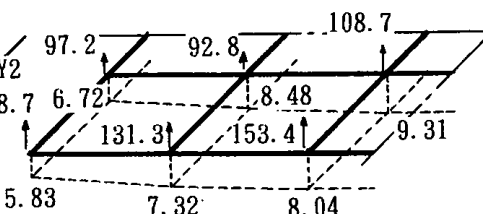

CASE-2

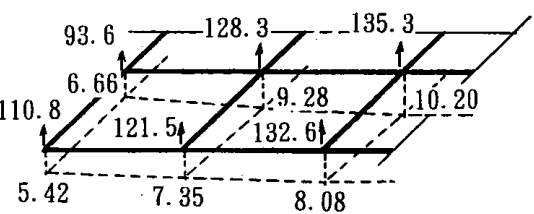

\begin{tabular}{ll}
\hline CASE-4 & CASE-5 \\
\hline
\end{tabular}
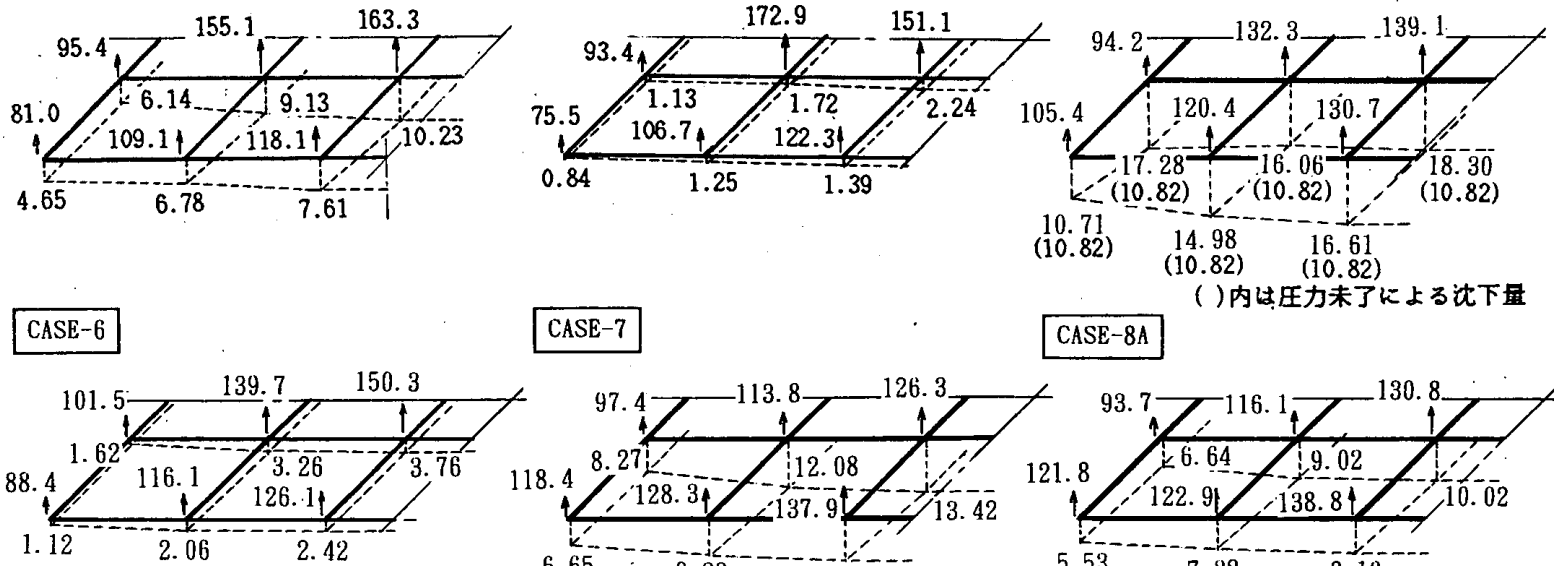

CASE-7 CASE-8A
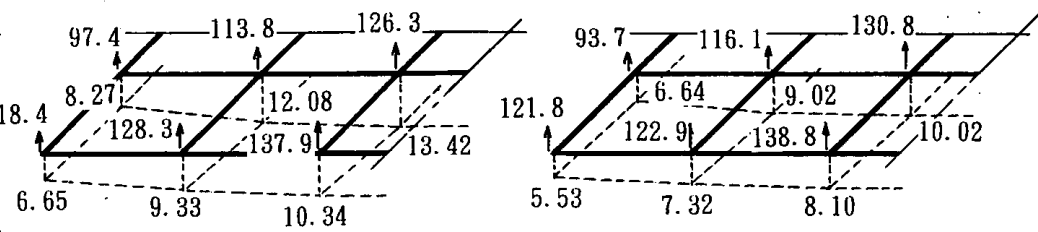

CASE-8C

CASE-8E

CASE-8D

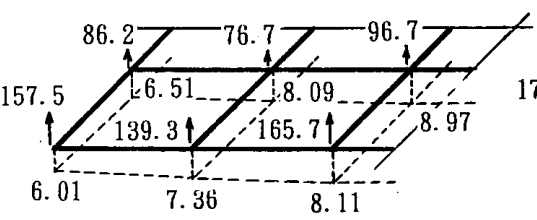

CASE-8G

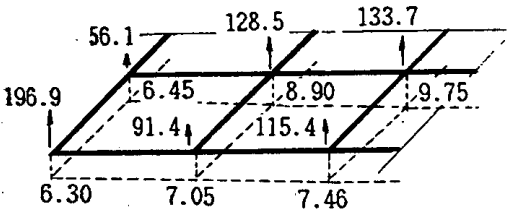

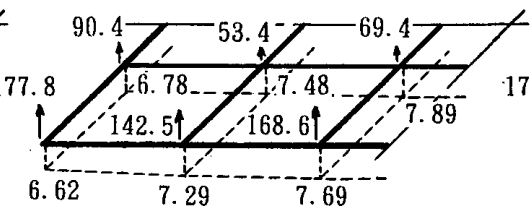

CASE-8F

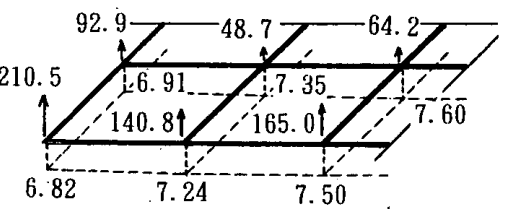

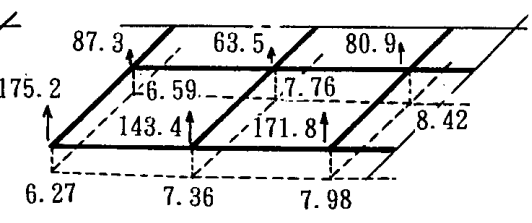

CASE-9

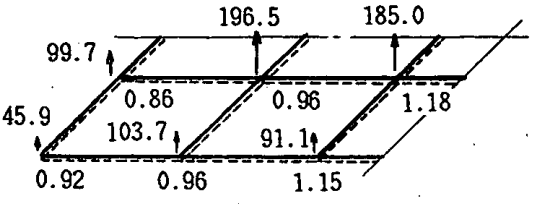

$\uparrow:$ 反力 $(t f)$ 、沈下量 $(\mathrm{cm})$

図一9＼cjkstart沈下量および反力分布 
2）部材の塑性化を考慮した CASE-2で は, CASE-1 に比べて视下量の均等化の 程度および荷重の移行の程度が小さくなっ ている。また, 部材応力はいずれも降伏モ一 メント以下に収まっている。この場合の最 大変形角は $3.85 \times 10^{-3} \mathrm{rad}$ であった。

3）部材の塑性化とクリープ変形を考虑し たCASE-3 は, CASE-2 よりさらに剛性 が低下し, 最大部材角は $4.76 \times 10^{-3} \mathrm{rad}$, 基礎梁の曲げ応力は CASE-2 に比べて約 $60 \%$, 部材を弾性とした CASE-1 の約 $45 \%$ の值となった。文献 22 では, 壁体に 有害なひび割れが発生する確率を目安とし て,鉄筋コンクリートが小さくなっている。 また, 部材応力はいずれも降伏モーメント 以下に収まっている。この場合の最大変形

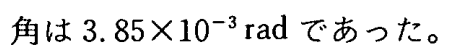

3）部材の塑性化とクリープ変形を考虑し た CASE-3 は, CASE-2 よりさらに剛性 が低下し, 最大部材角は $4.76 \times 10^{-3} \mathrm{rad}$, 基礎梁の曲げ応力は CASE-2 に比べて約 $60 \%$, 部材を弾性とした CASE-1 の約

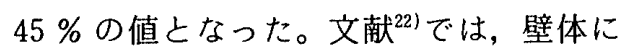
有害なひび割れが発生する確率を目安とし て，鉄筋コンクリート造ラーメン構造の許 容変形角の上限值を $2.0 \times 10^{-3} \mathrm{rad}$ として いる。通常のラーメン計算（基礎不動，鉛 直荷重時) の曲げモーメント值との複合を 考えたものとしても，その 2 倍 $(4.0 \times$ $\left.10^{-3} \mathrm{rad}\right)$ 程度でも, 通常寸法の基礎梁の 曲げ応力は降伏モーメント以下になる可能 性のあることが推測される。

4）粘性土が過圧密状態にある CASE-4 の沈下量はかなり小さいが, X 3 通り $\mathrm{Y}$ 1-Y 2 間の不同沈下応力は CASE-2 と比 較して 3 割程度しか低下しなかった。これ は, 建物中央部で粘性土の有効圧が圧密降伏応力を超え て (X 3-Y 2 基礎直下の上部粘性土層で $1.11 \mathrm{kgf} / \mathrm{cm}^{2}$, 下部粘性土層で $1.20 \mathrm{kgf} / \mathrm{cm}^{2}$ ), 圧密降伏応力以下であ る建物端部との沈下差が大きくなったためである。これ に対して, 有効生が任密降伏応力以下に収まっている $\mathrm{Y} 2$ 通りX 1-X 2 間では, 不同沈下応力の低下率が大き い。圧密未了の場合の CASE-5 では沈下量はかなり大 きくなるが, 圧密未了が原因で生じる地盤沈下量は均等 と仮定したため, 最大変形角, 部材曲げ応力とも CASE-2 の場合と比べてあまり変化していない。

5) 即時沈下を対象とした CASE-6 でも最大部材角が $2.44 \times 10^{-3} \mathrm{rad}$, 基礎梁応力が $51.3 \mathrm{tfm}$ 発生しており,
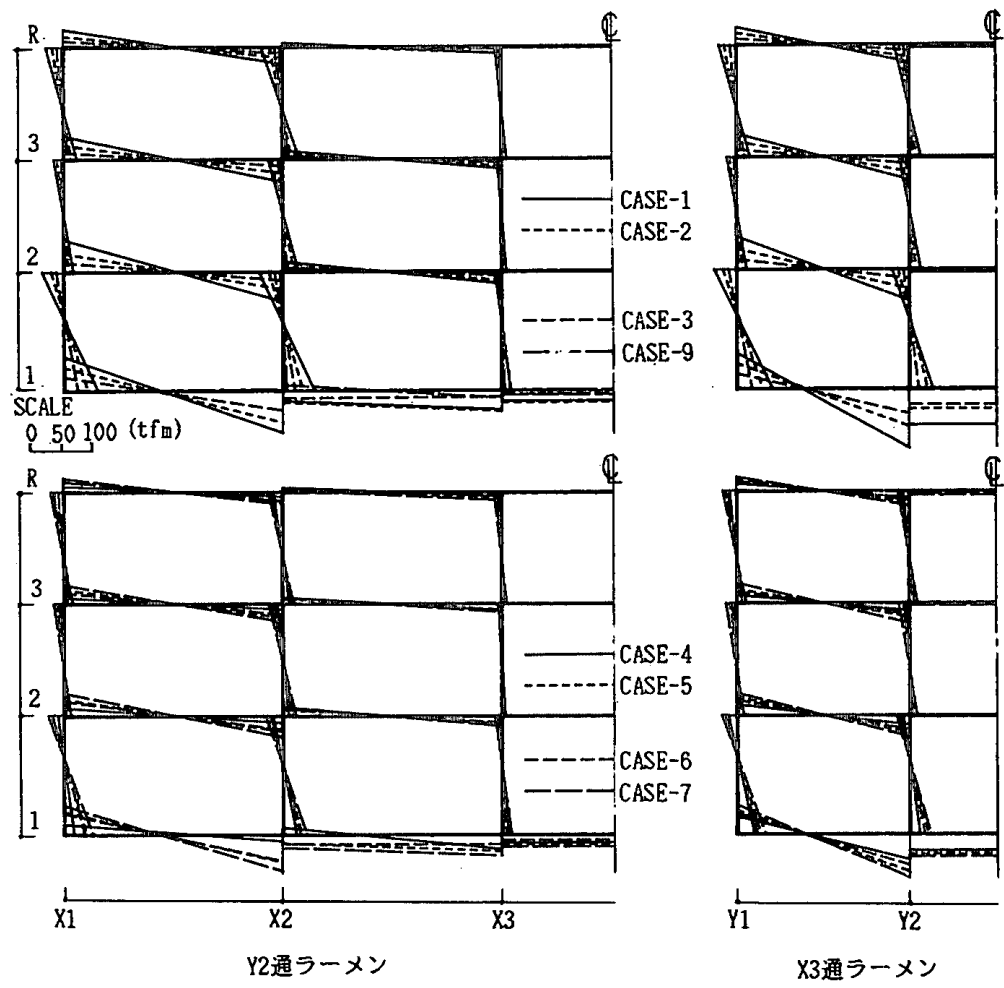

X3通ラーメン

図一10 曲げモーメント分布

表一3 最外端スパンの変形角と梁の曲げモーメント

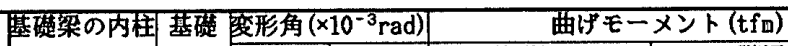

\begin{tabular}{|c|c|c|c|c|c|c|c|c|}
\hline \multirow[t]{2}{*}{ 計算CASE } & \multirow{2}{*}{ こ対する㓮比 } & \multirow{2}{*}{$\begin{array}{l}\text { 梁成 } \\
(\mathrm{cm})\end{array}$} & \multirow{2}{*}{$\begin{array}{l}X 3 \text { 通り } \\
Y 1 \text {-Y2間 }\end{array}$} & \multirow{2}{*}{$\begin{array}{l}Y 2 \text { 通り } \\
x 1 \sim x 2 \text { 間 }\end{array}$} & \multicolumn{2}{|c|}{ 基礎策 } & \multicolumn{2}{|c|}{ 2榷梁 } \\
\hline & & & & & $X 3, Y 1-Y 2$ & $12, x 1-x 2$ & $X 3, Y 1 \sim Y 2$ & $12, \mathrm{X} 1 \sim \mathrm{X} 2$ \\
\hline CASE-0 & \multicolumn{2}{|c|}{ 上部架橉なし } & 6.80 & 5.84 & & & & \\
\hline CASE-1 & \multirow{7}{*}{3.07} & \multirow{7}{*}{120} & 2.31 & 2.51 & $94.6(x)$ & 66.3 & $51.6(x)$ & $50.5(x)$ \\
\hline CASE-2 & & & 3.85 & 3.74 & 60.3 & 49.8 & 32.1 & 29.0 \\
\hline CASE-3 & & & 4.76 & 4.27 & 39.4 & 30.2 & 15.5 & 14.5 \\
\hline CASE-4 & & & 1.55 & 0.84 & 42.6 & 16.1 & 16.8 & 12.6 \\
\hline CASE-5 & & & 3.07 & 1.74 & 62.0 & 45.6 & 28.0 & 26.1 \\
\hline CASE-6 & & & 2.44 & 2.34 & 51.3 & 43.6 & 23.4 & 23.0 \\
\hline CASE-7 & & & 5.60 & 5.44 & $71.0(x)$ & 60.0 & $35.1(x)$ & $36.2(x)$ \\
\hline CASE-8A & 6.15 & 151 & 3.49 & 3.40 & 100.2 & 86.5 & 29.5 & 27.2 \\
\hline $8 \mathrm{~B}$ & 15.4 & 205 & 2.73 & 2.89 & 196.8 & 150.4 & 26.0 & 26.8 \\
\hline $8 \mathrm{C}$ & 30.7 & 259 & 1.56 & 2.26 & 326.0 & 229.5 & 18.9 & 22.0 \\
\hline 80 & 61.5 & 326 & 0.80 & 1.67 & 433.5 & 307.2 & 12.3 & 19.4 \\
\hline$\dddot{8 \mathrm{E}}$ & 154.0 & 442 & 0.36 & 1.00 & 482.9 & 420.9 & 9.3 & 13.8 \\
\hline $8 \mathrm{~F}$ & 307.0 & 557 & 0.18 & 0.63 & 508.1 & 493.1 & 5.5 & 11.6 \\
\hline $8 G$ & 訃周部のみ1 & 4.0 & 4.16 & $3.50^{\circ}$ & 62.7 & 47.9 & 34.0 & 31.0 \\
\hline CASE-9 & 3.07 & 120 & 0.05 & 0.14 & 2.2 & 3.5 & 0.1 & 0.9 \\
\hline
\end{tabular}

(×) 结曲け降伏発生を示す。
無視できない応力であることがわかる。ただし，即時沈 下が生じる時期には, 建物の剛性がまだ十分高まってい ないことをあわせ考える必要があろう。また, 即時沈下 終了後圧密沈下が続いて発生するとした CASE-7で は, 部材の剛性低下を考慮しても, 基礎梁・ 2 階梁には 曲げ降伏が発生した。建物の施工過程を考えると, 即時 沈下により生じる応力と圧密沈下の応力とを単純に加え る必要はないと考えられるが，この上うな現象に対する 何らかの配慮は必要であろう。

6）不同沈下軽減効果を考慮したCASE-8 A CASE$8 \mathrm{~F}$ の解析結果として, 基礎梁の内柱に対する剛比倍率 と X 3 通り Y 1-Y 2 間の変形角および曲げモーメント 


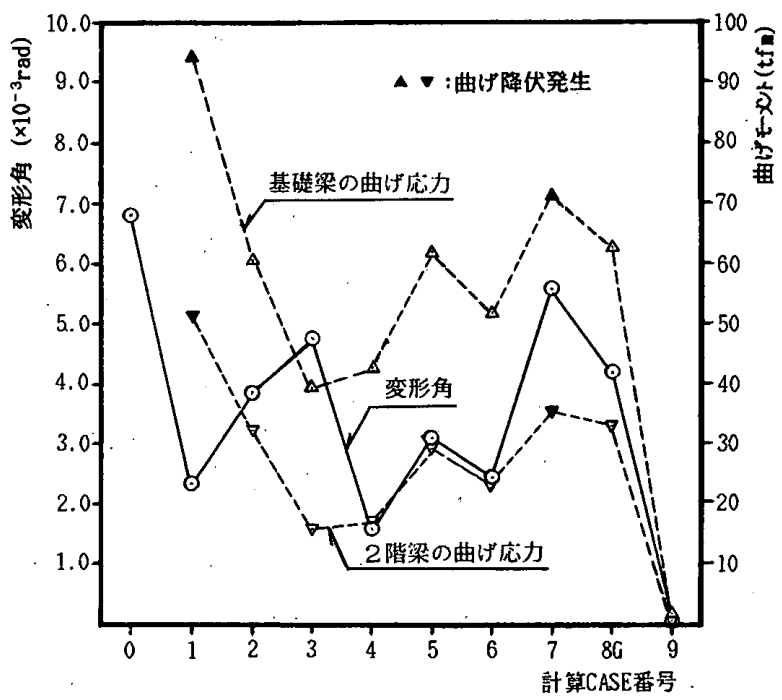

図一11 X 3 通 $\mathrm{Y} 1$ ～Y 2 間の変形角と曲げモーメント

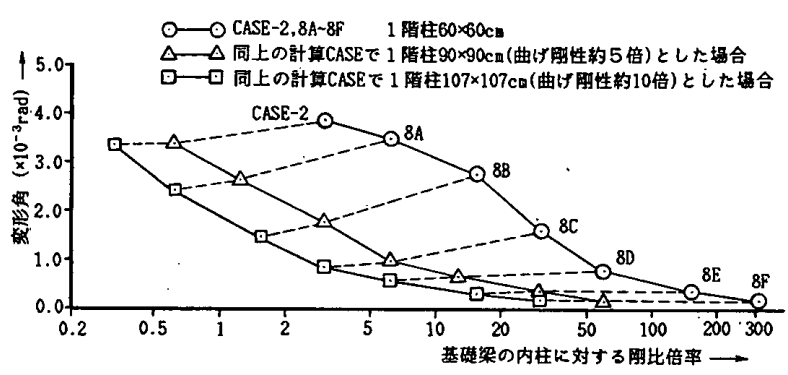

図一12 凮比倍率とX 3 通り Y 1-Y 2 間の変形角

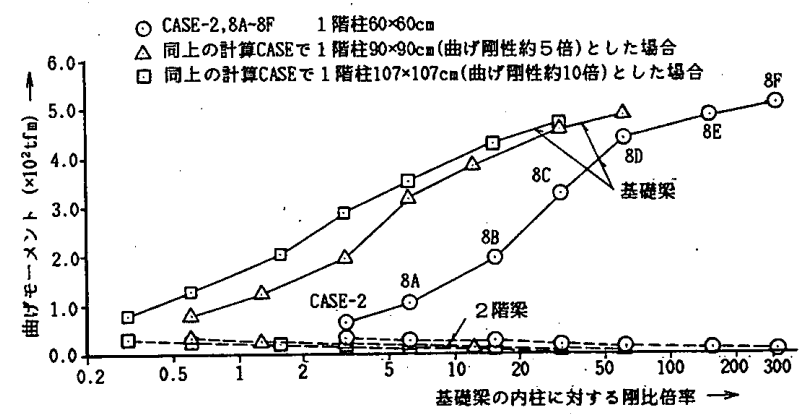

図一13 㴊比倍率とX 3 通り Y 1-Y 2 間の梁の曲げモーメント

の関係を図一 12 お.よび図一13に示した。基礎梁の剛性 が増大するに従って, 明らかに変形角が小さくなるとと もに，曲げ応力が基礎梁に集中する傾向があることがわ かる。図一12,13には，1階柱の断面を增大させた場合 を合わせて示した。1階柱の剈性を増大させることに よっても変形角はかなり小さくなることが分かる。した がって, 不同沈下軽減効果は基礎梁と内柱の剛比倍率だ けでは定量的な評価は難しく, 柱および梁を含めた建物 全体の剛性が関係することが分かる。現行の提案23i では， かなりの大きい不同沈下が予測される場合として，5８ 倍程度が示されているが, 再検討の必要があろう。剛性 増加を外周部の基礎梁のみに限った CASE-8Gでは, 変形角・曲げ応力とも CASE-2 と大差なく, 効果があ まり期待できないことがわかる。

7）浮基礎を想定したCASE-9 では，沈下量・部材応 力とも無視できる程度の小さな值となり，不同沈下軽减

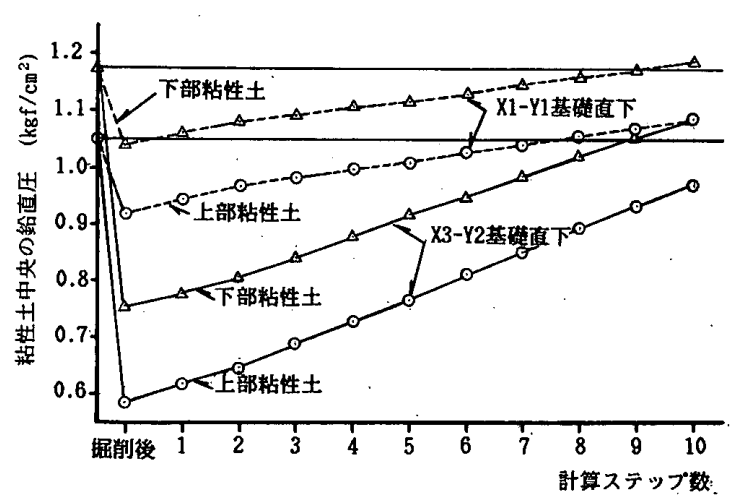

図一14 CASE-9 の粘性土層の鉛直圧の推移

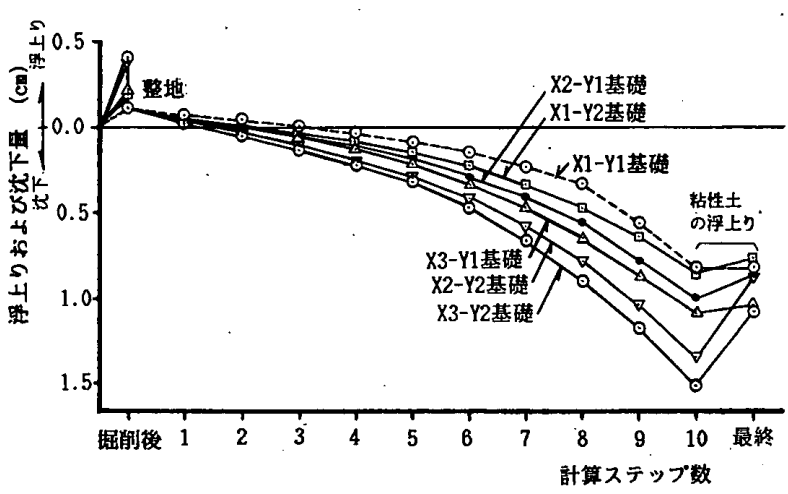

図一15 CASE-9 の地盤の浮き上がりと沈下の推移

効果の大きいことがわかる。また，各計算ステップにお ける粘性土層の鉛直圧の変化を建物中央部 (X 3-Y 2 基 礎）と建物隅部（X1-Y 1 基礎）に限って図一14に, 地盤の浮き上がり・沈下の推移を, 図一15に示した。 掘削に伴って; 粘性土層は鉛直圧が減少し, 砂質土層は 弾性的な地盤の浮き上がりが生じている。その後, 建物 荷重によって, 砂質土層は排土重量 $\left(5.4 \mathrm{tf} / \mathrm{m}^{2}\right)$ が建物 荷重 $\left(5.0 \mathrm{tf} / \mathrm{m}^{2}\right)$ より大きいにもかかわらず，すべての 基礎において浮き上がり量より大きな即時沈下が生じて いる。これは, 建物荷重が $3.0 \mathrm{~m} \times 3.0 \mathrm{~m}$ のフーチング を通して集中的に載荷されるため, 基礎直下の砂質土層 のひずみが掘削前より増大し, 弾性係数が低下したため である。一方, 粘性土層では, 上部構造の剛性によって 建物荷重が建物端部に移行し, 建物隅部 (X 1-Y 1 基礎) のみ掘削前の初期有効圧を超えて圧密沈下が計算ステッ プ 8 以降で発生している（図一14 参照）。その他の基礎 直下の粘性土層はいずれも掘削前の初期有効圧以下にと ぞまっていて，図一15 の最終計算ステップに示す終局 状態では，浮き上がりが生じている。このように浮基礎 では, 粘性土層が建物中央部では浮き上がり, 建物隅部 では沈下する傾向を示し，一般に建物中央部で大きくな る砂質土層の即時沈下を均等化させて, 不同沈下軽減効 果が発揮されていることがわかる。

6. まとめ

以上, 基礎と上部構造の変形を適合させ, 地盤の非線 形性および上部構造の非線形性を考慮した応力解析手法 
を提案した。上部構造の設計に多用されている 3 次元骨 組解析プログラムに, 地盤の変形を組込むことによって 構成したものであって, 従来なおざりにされていた不同 沈下解析を, 実用的な設計手法として確立することがで きたと考える。粘性土の圧密沈下を 1 次元圧密に限定し ていること, 沈下の経時変化を無視していること, 上部 構造の塑性化・クリープの扱いにかなりの近似化を行っ ていることなど，問題点はまだ多く含んでいるが，実設 計に利用することを考えた場合, 大局的には許される範 囲にあると判断される。

また, 本解法によって行った解析事例より，以下の事 項を明らかにすることができた。

1）不同㶩下解析を行うと, 上部構造の応力は弾性範囲 を超えることが多く, 現夷的な応力を求めるには部材の 塑性化やクリープの影響を考慮する必要がある。

2）粘性土の過圧密・正規圧密・圧密未了状態を通じて の解析の可能性が確かめられた。過圧密地盤であっても, 建物建設後に建物の中央部などで部分的に有効王が圷密 降伏応力を超える場合には, 相対沈下量が増加して, 無 視できない部材応力が生ずることがある。

3）上部構造部材の塑性化・クリープを考慮すると, 鉄 筋コンクリート造ラーメン棈造の場合, 現行の許容変形 角の上限值 $2.0 \times 10^{-3} \mathrm{rad}$ の 2 倍程度であっても通常寸 法の基礎梁に曲げ降伏が発生しない可能性がありえる。 現行の許容変形角は, 壁体などのひび割れの有無など視 覚的な判断によって提案されたものであり, 今後部材応 力によって再検討することが必要であろう。

4）不同沈下の発生が予想される場合には，基礎梁の剛 性の増大, さらには 1 階柱の㴊性も増大させることが望 ましい。現行の提案では, 基礎梁の内柱に対する剛比倍 率を5〜8倍程度にすることが推奖されているが，この 剛比倍率だけでは定量的な評価が難しいことが分かる。 5）浮基礎の場合, 砂質土層の即時沈下は建物中央部で 大きくなる傾向がある。また，上部構造の剛性によって 建物荷重が建物端部に移行し，建物隅部直下の粘性土で は有効玨が掘削前より増加して圧密沈下が生じ，建物中 央部では逆に有効圧が掘削前より減少して浮き上がりが 生じる傾向にあることがわかった。これらの現象により， 建物の沈下が均等化され，不同沈下軽減効果が大きく発 揮されている。

\section{参考文献}

1）日本建築学会：建築基礎構造設計指針, pp. 156 163, 1988. 1

2）横尾義貫，山肩邦男：地下粘性土層の圧密による建築物 の不同沈下について, 日本建築学会諭文報告集, 第 50 号, pp. 88 $\sim 94,1955.3$

3）横尾義貫，山肩邦男，佐藤 寛：軟弱地盤における建築 物の不同沈下対策に関する基礎的考察，日本建築学会論 文報告集，第 65 号，pp. $25-33 ， 1960.6$
4) Chamechi Samuel : Structural Rigidity in Calculating Settlements, Proc, ASCE, Vol.82, No.SM1, pp.1 $19,1956.1$

5）大崎順彦：不同沈下による上部構造応力の理諭解および 実用近似解法, 建築研究所研究報告, No. 18, pp. 1 10, 1956. 3

6）松浦 誠：構造物の剛性を考慮した不同沈下の実用算定 法, 日本建築学会論文報告集, 第 66 号, pp. $617 \sim 620$, 1960.10

7）中田啓一，山肩邦男：杭基礎を持った建築構造物の沈下 に関する理論的研究（第 1 4 報）, 日本建築学:会論文報 告集, 第 274 号, pp. 55 64, 1978. 12 ; 第 275 号, pp. 15 -23, 1979.1 ; 第 277 号, pp. 63 70, 1979. 3 ; 第 321 号, pp. $97 \sim 107,1982.11$

8）松浦 誠, 山本春行：鉄筋コンクリートラーメンの非線 形および時間依存性を考慮した不同沈下に関する理論的 研究, 広島大学工学部研究報告, 第 30 巻第 1 号, pp. 65 $\sim 74,1981.1$

9）松浦 誠, 山本春行：軟弱地盤上のベ夕基礎を有する構 造物の不同沈下に関する解析的研究, 日本建築学会論文 報告集，第 331 号，pp. 18～26，1983.9

10）土屋 勉, 大築和夫, 小幡 守：軟弱地盤における建築 構造物の即時视下および圧密沈下の 3 次元有限要素法解 析，日本建築学会構造系論文報告集，第 361 号, pp. 123 $\sim 131,1986.3$

11）土屋 勉，大築和夫，小幡 守：軟弱地盤に支持された 建築構造物の沈下過程に関する実用算定法, 日本建築学 会構造系論文報告集，第 383 号, pp. 109 117, 1988.1

12）山肩邦男：建築基礎工学, 朝倉書店, pp. $275 \sim 284$, 1990.4

13）山肩邦男，松尾雅夫：地盤の変形を考虑した鉛直荷重時 ラーメン解法について, 第 23 回土質工学研究発表会講演 集，pp. 1233 1234，1988.6

14）松尾雅夫，山肩邦男：地盤の変形を考慮した鉛直荷重時 ラーメン解法 (その 2 ), 第 27 回土質工学研究発表会講 演集，pp. 1715 1716，1992.6

15）松尾雅夫, 山肩邦男：過圧密および圧密未了地盤の変形 を考虑した鉛直荷重時ラーメン解法について, 日本建築 学会大会学術講演梗概集, pp. 1417 1418, 1992.8

16) K. Terzaghi : Theoretical Soil Mechanics, John Wiley \& Sons. Inc., pp. 423 425, 1943

17）1）に同じ, pp. 148 149

18）植下 協，松井克俊，大岡 武，永瀬信一：地盤の挙動 計測による建築基礎の合理化の例，土質工学会論文報告 集, Vol. 13，No. 3，pp. 87 95，1973.9

19）秋野矩之：地盤の剛性評価之建物の沈下予測一建築物の 即時沈下予測方法 (その1), 日本建築学会構造系論文報 告集, 第 412 号, pp. 109 119, 1990.6

20）日本建築学会：鉄筋コンクリート構造計算規準・同解説, pp. $63 \sim 69,1991.4$

21） 六車 熙：コンクリートのクリープと鉄筋コンクリート 構造物, 鉄筋コンクリートの諸問題, 日本建築学会近畿 支部, pp. $48 \sim 69,1972$

22）1）に同じ, pp. 156 157

23） 1)に同じ, pp. 162

(1993 年 3 月. 3 日原稿受理, 1993 年 10 月 28 日採用決定) 